\title{
SALAMON KIRÁLY TORNYAI \\ Új adatok a Sibrik-dombi erőd római- és középkori építéstörténetéhez
}

\section{Boruzs Katalin - BuZás Gergely ${ }^{1}$}

Magyar Régészet 10. évf. (2021), 4. szám, pp. 39-47. https://doi.org/10.36245/mr.2021.4.1

A Magyar Nemzeti Múzeum Mátyás Király Múzeuma 2013-ban indította újra kutatásait a mai Visegrád városától mintegy másfél kilométerre lévö Sibrik-dombon, a római kori tábor és középkori ispáni központ területén. Az elmúlt nyolc év alatt számos unikális lelet került napvilágra, amelyek bebizonyitották, hogy az 5. századot követöen már legkésőbb a 9. század elsö felétől használták az erödítményt, amely fontosságát egészen a 13. század elsö harmadáig megörizte. A délnyugati táborrész 2019-2021 között, Boruzs Katalin által végzett feltárása során két római kori torony mellett két, eddig ismeretlen középkori torony is napvilágra került. Segitségükkel lehetöség nyílott a korábbi ásatások periodizációjának reviziójára és a vár középkori történetének egy eddig alig ismert korszaka tárult fel.

Kulcsszavak: erődítmény, torony, kváder, lizéna, római kor, középkor, Sibrik-domb, Visegrád

\section{KUTATÁSTÖRTÉNET}

Idén 70 éve, 1951-ben kezdődött az erőd első régészeti kutatása Soproni Sándor vezetésével. Ekkor a mezőgazdasági müvelés alatt álló területen csak kutatóárkokkal nyílt lehetőség a lelőhely szondázására (Soproni, 1954). 1970-1976 között Soproni Sándor és Szőke Mátyás vezetésével már nagyobb felületen, az erőd nyugati és délkeleti részén folyhatott feltárás (SOPRONI \& SzŐKE, 1972; 1975; 1976; 1977). Ekkor fény derült az erőd méreteire, főfalainak elhelyezkedésére, több külső torony helyére is. Az építészeti megoldások, a rétegviszonyok és a leletanyag alapján három római kori és három középkori periódust határoztak meg. A tábor építését Kr. u. 325-330 közé keltezték az I. Constantinus idején meginduló éremforgalom és a toronyformák alapján. A nyugati táborfal közepén feltárt jelenségek alapján egy 4. század közepi (kétosztatú kapu) és egy Valentinianus-kori (négyzetes torony) építési periódust is feltételeztek. Az erődítmény belterületén, közvetlenül a föfalakhoz csatlakozva három római kori kőépületet, kissé beljebb egy középkori palotát, valamint számos földbe mélyülö objektumot is feltártak (BuzÁs et al., 2017, 195-203), ennek ellenére a nagy területü erőd beépítettsége alig ismert.

\section{AZ ÚJABB KUTATÁSOK ÉS EREDMÉNYEI}

A belső területhasználatra a 2010-ben végzett geofizikai felmérés szolgáltatott új információkat (BuzÁs et al., 2014) és ezzel új lendületet adott a kutatásnak. A máig beépítetlen lelöhely 2013-2021 között végzett szisztematikus kutatása a római kori, kora középkori és Árpád-kori ismereteinket is jelentősen bővítette (1. kép). A római kori belső épületek és ciszterna dokumentálása, a táborkapu feltételezhető helyének szondázása, a 8-9. századhoz köthető nemesfémolvasztó kemencék, a 10-11. század fordulójához köthető apszisos templom és temetkezései, a két 11-12. századi torony és a 13. század első harmadához köthető verőtöveket rejtő földbe mélyülő ház feltárása fontos új adatokkal gazdagította a lelőhely történetét.

\section{Római kor}

A legújabb feltárások eredményeként tisztázódott a délnyugati erődfal 35 m-es szakaszának enyhén ívelt vonala. Kb. 18 m hosszan 2-5 kősor magasságig maradt fenn a törtkőből készült, $1 \mathrm{~m}$ vastag falazat. A

\footnotetext{
1 A Magyar Nemzeti Múzeum Mátyás Király Múzeuma, Visegrád. E-mail: boruzskatalin@,visegradmuzeum.hu; buzasgergely@, visegradmuzeum.hu
} 

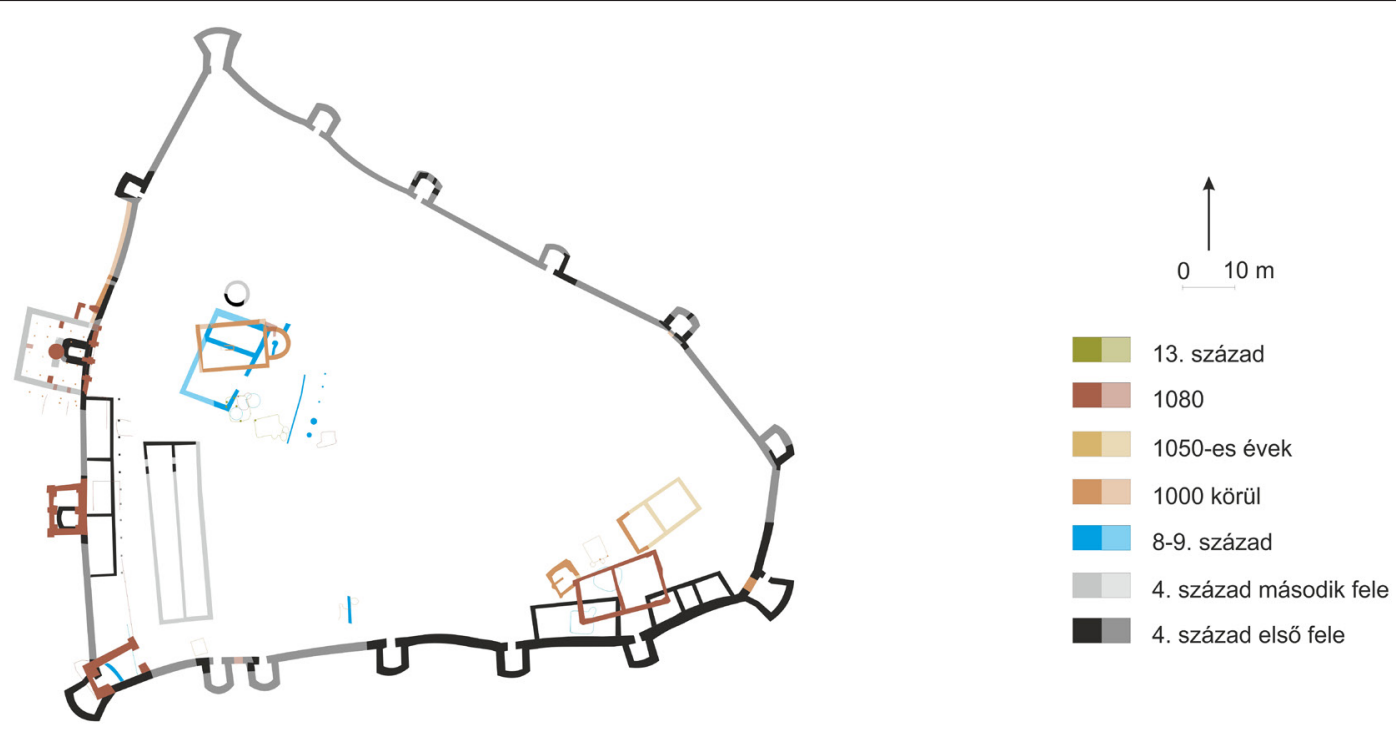

1. kép. A visegrádi római eröd és koraközépkori vár periodizált alaprajza (rajz: Buzás Gergely)

falszakasz középső tornyától még mintegy 2,5 m hosszan jól látható a római kori táborfal, de ettől kezdve egészen a saroktoronyig az alapozási árok aljáig visszabontották az erődfalat. A falkiszedésből Gordianus érméje mellett II. István (?) ezüstje és vas késtok-merevítö töredéke került napvilágra. A délnyugati táborfal vége - egyúttal a délnyugati saroktorony bejárata - részben fennmaradt (2. kép).

Sor került a délnyugati erődfal-szakasz közepén elhelyezkedő, U-alakú külső torony teljes területének kutatására, valamint a Soproni Sándor által már dokumentált délnyugati, legyező alakú saroktorony hitelesítő ásatására is. Az U-alakú torony, amely a táborfallal egy időben épült, méretei és kialakítása révén a déli oldal tornyaihoz hasonló. $90 \mathrm{~cm}$ széles bejáratát a föléje emelt középkori torony építésekor falazták be. A toronybelsőben, a 15-20 cm vastagságú, római korhoz köthető agyagos feltöltés és járószint bontása során két jó állapotú, Kr. u. 300 és 305 között vert Sacra Moneta hátlapos érme került napvilágra. A délnyugati saroktorony területén, a fekete faszenes égett omladékrétegből mintegy 30 római kisbronz, nyersszínű hombár és szürke házikerámia töredékek mellett I. Constantinus időszakához köthető Quadriburgium bélyegtöredékes tegula is előkerült.

Egy-két kősor magasságig őrződött meg a délnyugati saroktoronytól induló déli táborfal-szakasz, amelynek $5 \mathrm{~m}$ hosszan feltárt szakasza a nyugati főfalhoz hasonló kialakítású volt. A 10 m-re keletre húzott kutatóárokban ugyanennek a déli falnak már csak az alapozását találtuk meg, amely $190 \mathrm{~cm}$ szélességü. A kutatóárokban a főfalból déli irányban

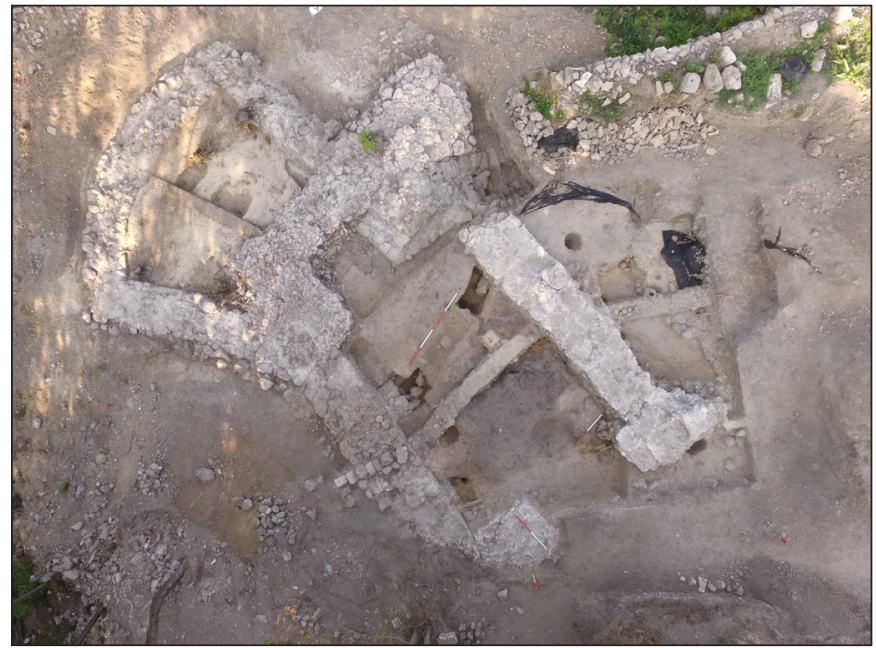

2. kép. A délnyugati saroktorony feltárása 2021-ben (fotó: Boruzs Katalin) 


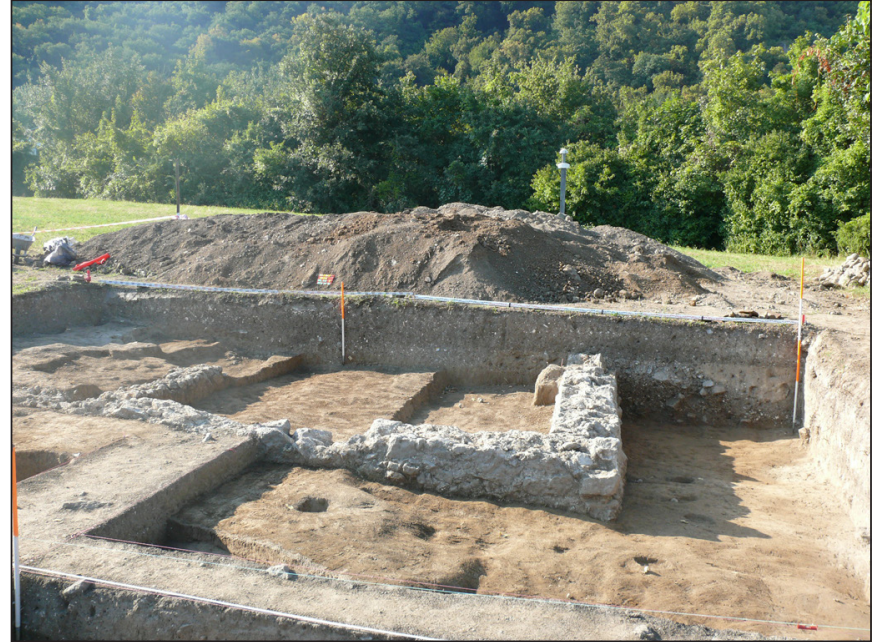

3. kép. A római kori „E” épület északi vége (fotó: Boruzs Katalin)

egy 130-150 cm széles alapozású falszakasz indul, ami talán egy torony helyét jelzi. Soproni Sándor 1951/6. kutatóárkával és az ott feltételezett torony elhelyezkedésével összevetve úgy tünik, hogy egymástól mintegy $8 \mathrm{~m}$-re két torony állhatott, ami arra utal, hogy itt keresendő az erőd római kori kapuja.

Az erődfalon belül napvilágra került az 1976-ban feltárt római kori tornácos épület („D” épület) második és harmadik helyisége, padló alatt futó, $\mathrm{K}-\mathrm{Ny}-\mathrm{i}$ irányú, kövezett csatornával és tapasztott agyagpadlóval. A csatorna a táborfalon kialakított, kb. $25 \mathrm{~cm}$ átméröjű nyíláson át vezette a falon kívülre a vizet (?). A termek ajtónyílásai a keleti oldalon helyezkedtek el. Az északi helyiséghez hasonlóan keletről $80 \mathrm{~cm}$ széles tornác határolta ezt az épületrészt is, amit oszloptartó kövei jeleznek. A harmadik helyiség déli falának csak kiszedett és törmelékkel feltöltött helye került napvilágra, így jelenleg még nem bizonyítható, hogy a helyiségsor déli irányban folytatódik. A D/3. helyiség az U-alakú torony előterében helyezkedik el, tehát ennek a toronynak a megközelítése az épületből történt - ellentétben a délkeleti részen feltárt tornyokkal.

A táborfalhoz támaszkodó „D” épülettől kb. 4 m-re keletre, vele párhuzamosan egy másik építmény helyezkedett el („E” épület), amelynek északi részét a 2018. évi ásatás hozta napvilágra (3. kép). Az épület alapozásakor a domb természetes vonalát követték, így a nyugati és keleti fal alapozási szintje között kb. 50 cm-es szintbeli eltérés van. Ebböl (is) következik, hogy a nyugati oldalon jó állapotban, az alapozási kiugrás felett a második, helyenként a harmadik kősorig fennmaradt a fal, míg a keleti oldal az alapozásig lepusztult. A helyiség 4,2 m széles, hossza egyelöre nem meghatározható - a georadaros felvételek alapján kb. 25-30 m lehet. A falak mellett lévő cölöphelyek alapján arra lehet következtetni, hogy a nyugati oldalon $70 \mathrm{~cm}$, az északi oldalról $90 \mathrm{~cm}$ szélességü nyitott folyosó vette körbe. Az eddig feltárt épületrész középkori használatára utal Szent László ezüstje és egy friesachi denár, csupán a legalsó, vékony réteg köthető a római korszakhoz, amiböl a mindennapi élet kellékei és viseleti elemek (érmek, fibulatöredékek, vas kés és övveretek) láttak napvilágot.

Az utóbbi években a feltárásokon rendszeresen használt detektornak köszönhetően ${ }^{2}$ ugrásszerüen megnőtt a fémtárgyak száma. 2013 és 2021 között több mint 1300 db római kori bronzérme került elö, így egyre árnyaltabb képet kaphatunk a 4. század pénzügyi viszonyairól. ${ }^{3}$ A területről származó legkorábbi (és eddig egyetlen 2. századi) veret Commodus sestertiusa, néhány bronzpénz köthető a 270-es évekhez, de a begyüjtött leletanyag döntő többsége a 4. századra datálható. A 3. század utolsó harmadára keltezhető, igen kopott bronzérmek közül az egyik a délkeleti saroktorony agyagos padlójába volt betaposva. Ezek értékelése kérdéses: az erőd építőihez vagy inkább egy korábbi periódushoz köthetők? Ez utóbbit támasztják alá a bélyeges téglák is, amelyek között csak a 4. századhoz köthető típusok fordulnak elő (BoRUzs, 2021, 20-23).

\section{Középkor}

A 2019-2021-es ásatások során az erőd délnyugati sarkában egy 8-9. századi kerámiával keltezett paticsfalu faház omladéka és egy színesfémolvasztó kemence került elő. A kemence tüzpadkáján aranyolvadék feküdt. Valószínüleg ebben a korszakban készülhetett a délnyugati, legyező alaprajzú római saroktorony belső ajtaja előtt épített íves alaprajzú, kövekkel betöltött cölöpfal-alapárok is.

Ezúton is köszönjük Horváth István, Molnár Gergely, Kovács Gergely, Kocsis László, Pálinkási Hunor és Viski Gábor munkáját.

3 A lelőhely római kori érméit Vida István (Magyar Nemzeti Múzeum, Éremtár) dolgozza fel. Köszönjük, hogy előzetes eredményeit felhasználhattuk. 


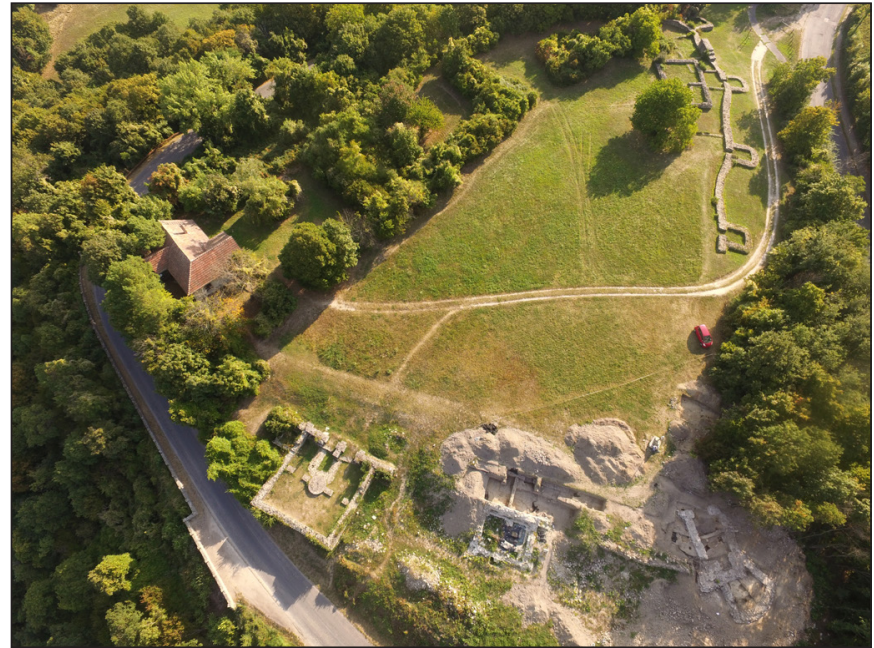

4. kép. A vár délnyugati falszakaszán feltárt tornyok 2021-ben (fotó: Boruzs Katalin)

Egy későbbi periódusban a római saroktornyot lebontották, és mögé, a várfalak sarkába egy kissé trapéz alaprajzú, $7 \times 11 \times 8$ m-es alapterületü, kváderfalú új kaputornyot emeltek (4. kép). Az északról szomszédos $U$ alaprajzú római tornyot is visszabontották és fölé egy $9,5 \times 6,5$ m-es alapterületü, kváderfalú, sarkain és a hosszoldalának közepén lizénákkal tagolt torony épült (5. kép).

Észak felé a következő torony a nyugati várfal középső tornya volt. Ezt 1971-ben és 1976-ban Szőke Mátyás és Soproni Sándor tárták fel (6-9. kép). Az ő kutatásuk során derült ki, hogy eredetileg itt is egy kisméretü, U-alakú torony állt. Ezt a tornyot később visszabontották, majd a helyén felépítettek egy $13 \times 13$ méteres alapterületü, $110 \mathrm{~cm}$-es falvastagságú nagy tornyot. Ennek a római falakkal egyező törtköves falazásmódja és kavicsos habarcsa alapján az ásatók joggal feltételezték, hogy még szintén a római kor-

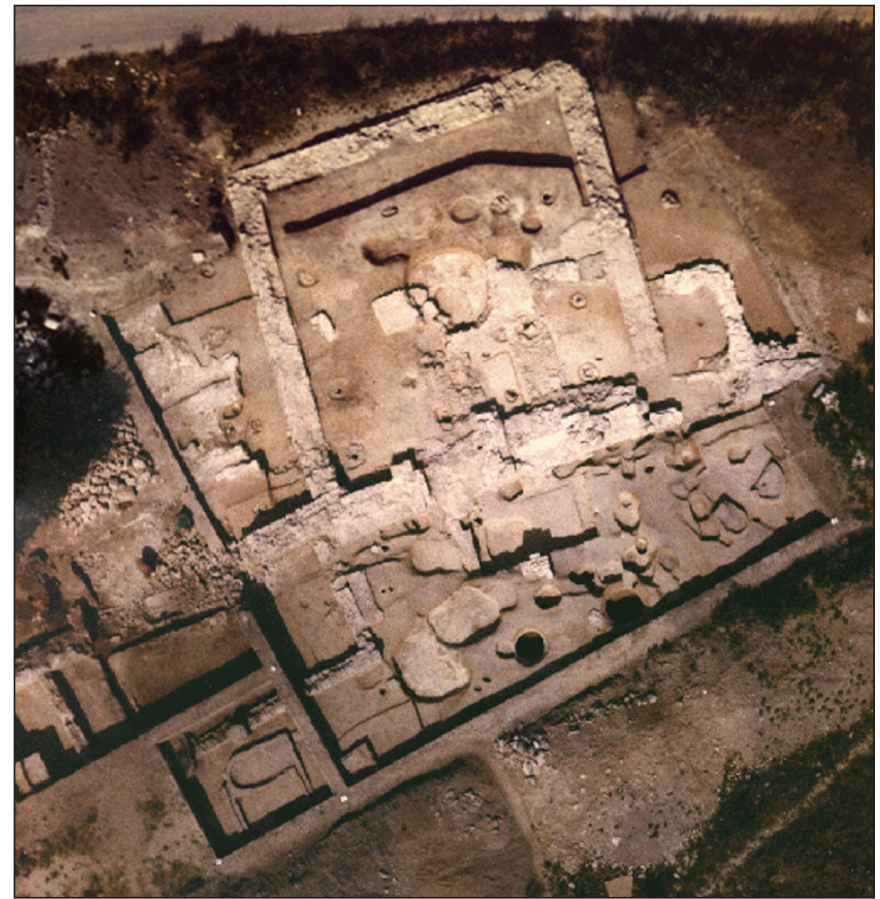

6. kép. A nyugati nagy torony feltárása 1976-ban (fotó: Szöke Mátyás)

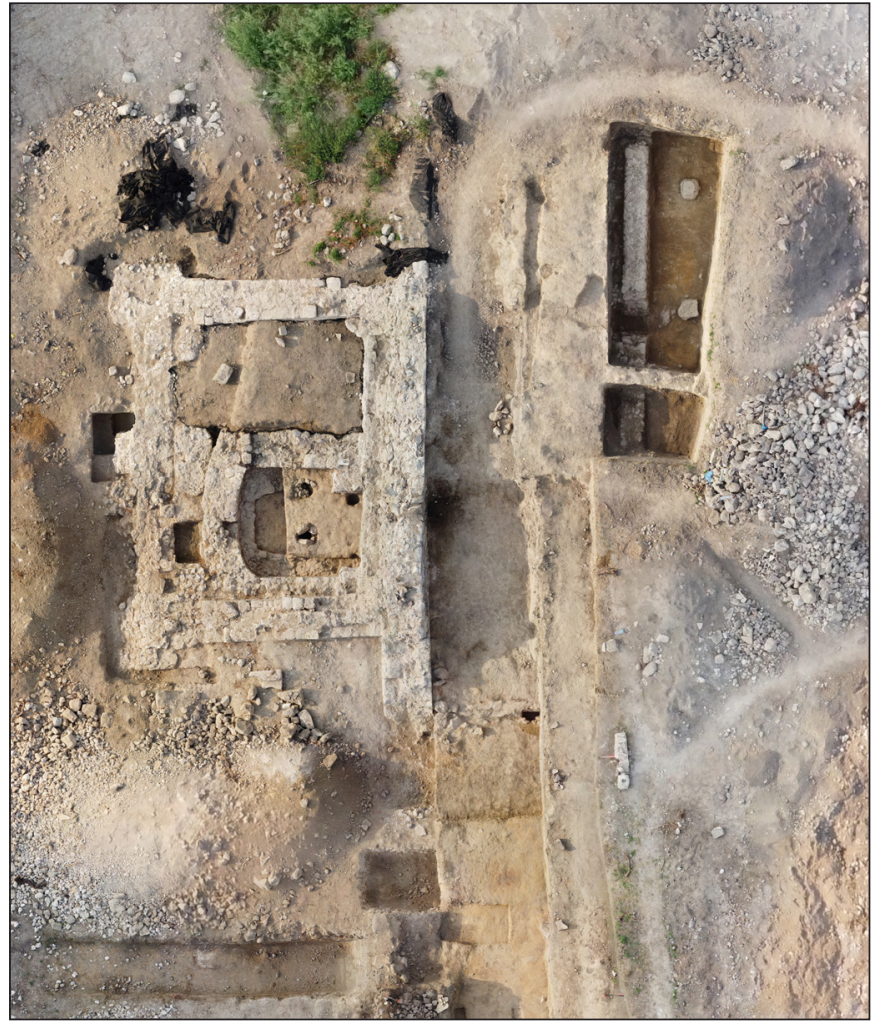

5. kép. A lizénás középkori torony és mögötte a római kori

„D” épület feltárása 2020-ban (ortofotó: ifj. Rétfalvi Teofil) ban épült. A toronynak a vár belseje felé nézö fala azonban a többitől eltérően mindössze $80 \mathrm{~cm}$ vastag kváderfal volt, amit mindkét oldalán lizénák tagoltak és egy kettős kapu tört át. E kapu szintje mintegy $70 \mathrm{~cm}$-el feljebb volt a négyzetes torony eredeti padlószintjénél, így azzal egykorú biztosan

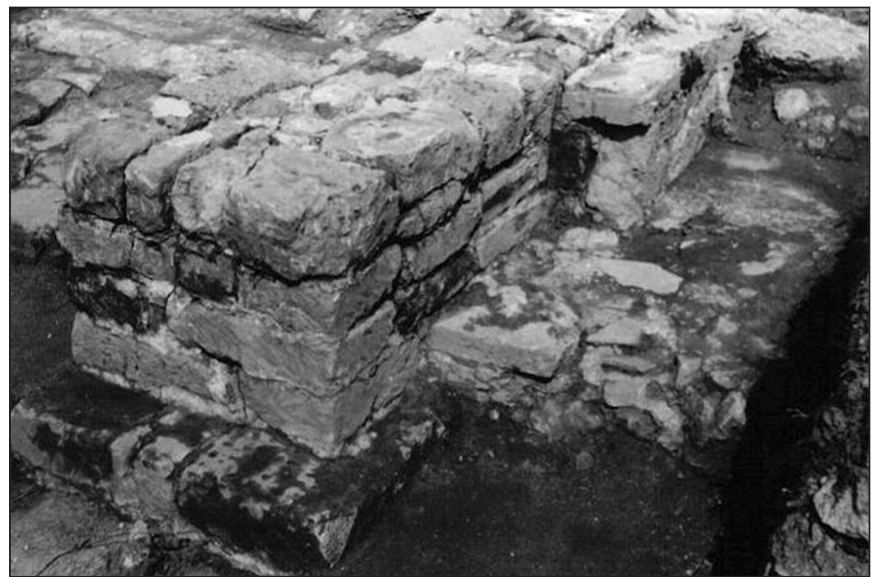

7. kép. A nyugati nagy torony kettös kapujának kváderfalazata 1971-ben (fotó: Szöke Mátyás - Soproni Sándor) 


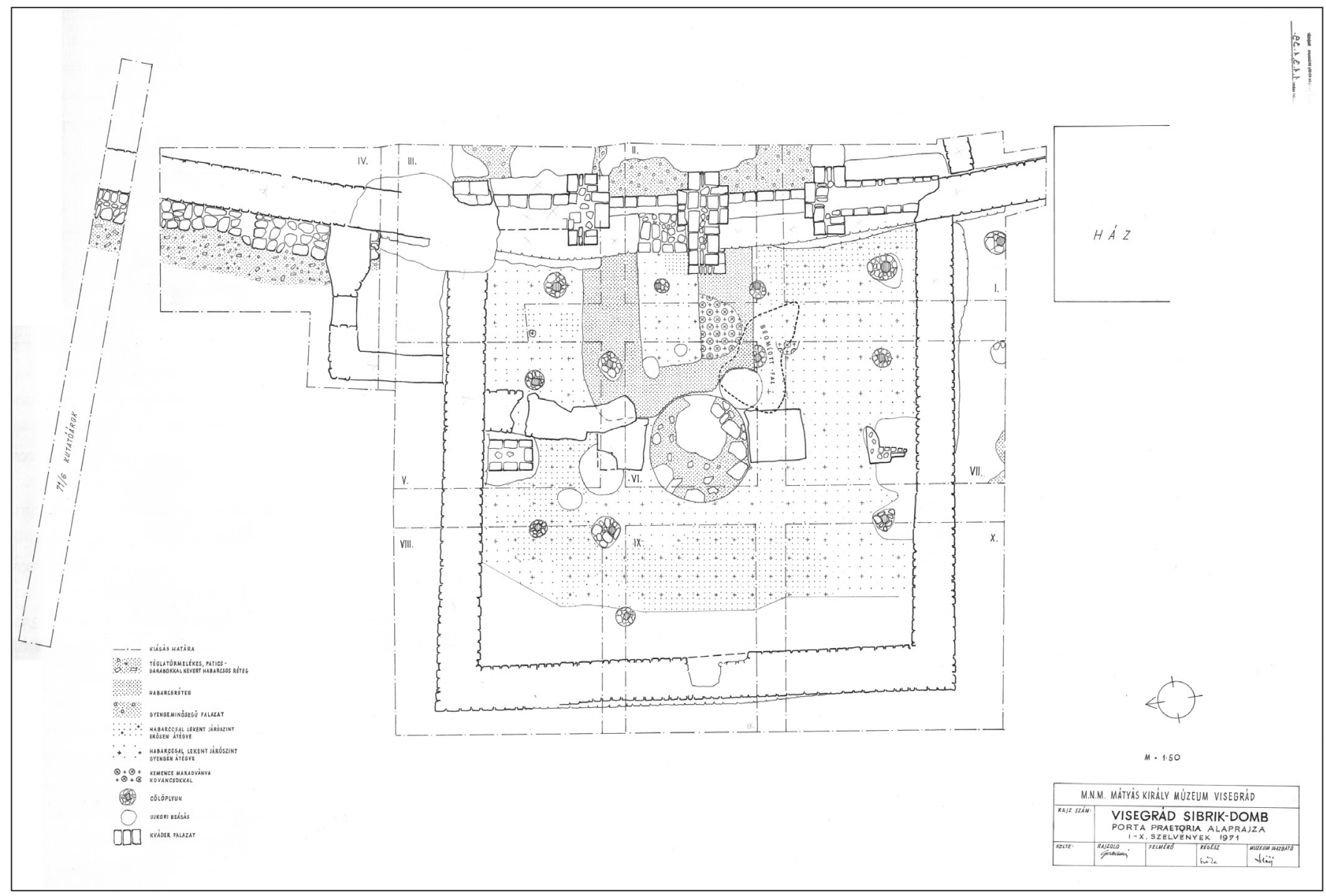

8. kép. A nyugati nagy torony 1971-es ásatási alaprajza (rajz: Szőke Mátyás - Soproni Sándor)

nem lehetett. Az ásatók - minden bizonnyal a kettős kapu formájából kiindulva - ezt is a rómainak tartották, és egy közbülső római periódusba sorolták. Azt gondolták, hogy a nagy torony építésekor a kettős kaput elfalazták, és a hozzá tartozó külső járószintet lesüllyesztették (SoProni \& SzÖKE, 1972). Ennek az elméletnek azonban több körülmény határozottan ellentmond. Az egyenes irányú kváderfalat a nála vastagabb, eredetileg kissé íves vonalvezetésű erődfalnak nem a külső, hanem a belső síkjához igazítva építették fel, a két fal vastagsága közti 30-50 cm-es falsíkváltás így az erődfal külső síkján jelentkezik, mégpedig pontosan a nagy négyzetes torony belső sarkaiban, ami csakis úgy értelmezhető, hogy a kváderes falat már a négyzetes toronyhoz igazítva építették fel. Ezt támasztja alá az is, hogy a kváderes falon nyíló kettős kapu

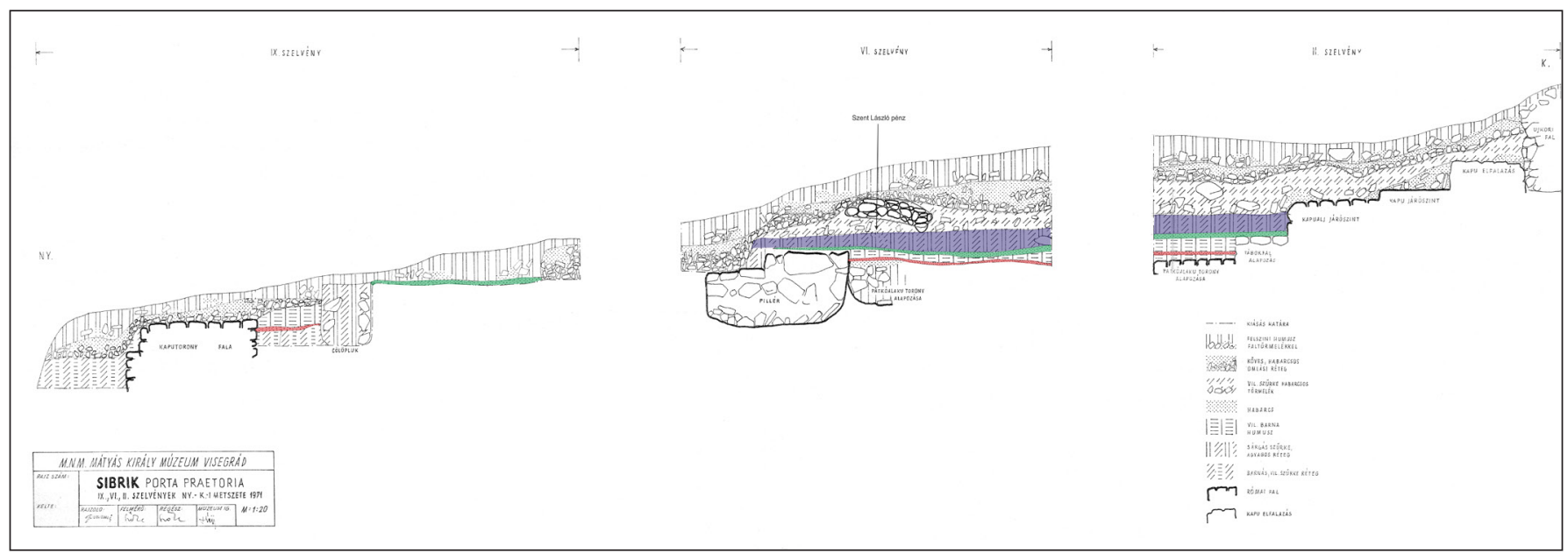

9. kép. A nyugati nagy torony rétegeinek K-Ny-i irányú metszete 1971-ben. Piros: római kori szint, zöld: elsö 11. századi padlószint, kék: második 11. századi feltöltés (rajz: Szőke Mátyás - Soproni Sándor) 


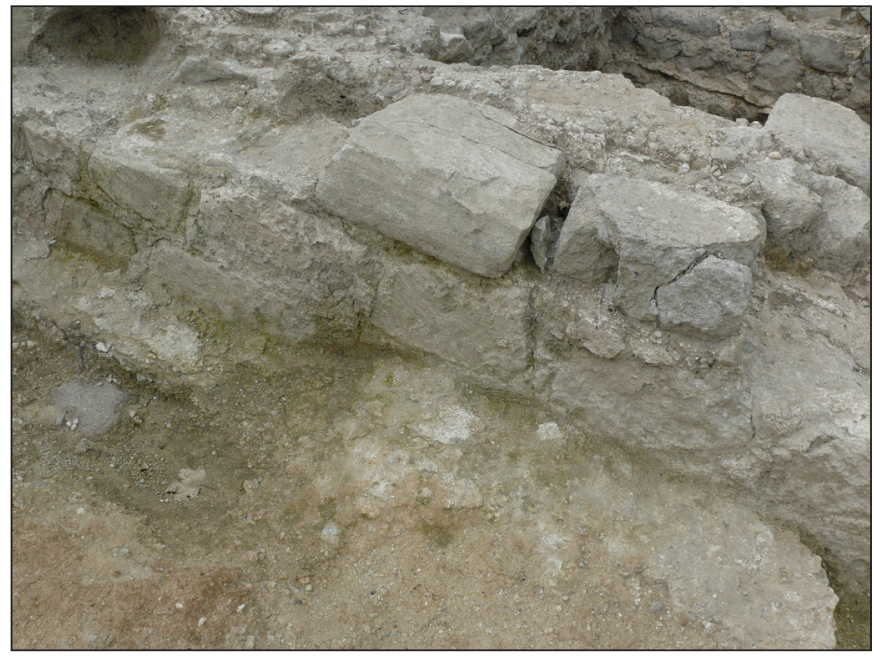

10. kép. A lizénás torony kváderfalazata (fotó: Boruzs Katalin)

középpillére a torony belseje felé egy hosszabb nyúlvánnyal rendelkezik, amihez hasonló, szintén kváderes pillérek maradványai előkerültek a négyzetes torony északi és a déli falának belső oldalához középen, utólag hozzáépítve is. Feltehetően lehetett egy negyedik ilyen pillér is a nyugati fal belső oldalának közepén, itt ugyanis egy újkori falkiszedés gödrét találták az 1971-es ásatás során. Hasonló újkori rablógödrökkel bontották szét az északi és déli falpillért, sőt a torony közepén egy nagy kerek pillért is, amely ugyancsak kváderekből épült. Akettős kapu elfalazása maradványának vélt habarcsréteg, amelynek külső oldalán kváderlenyomatokat találtak, egy faragott kövekből épített lépcső alapozása lehetett, amely a toronybelső járószintjét a vár nála magasabban lévő udvarszintjével kötötte össze. Márpedig ha a kettős kapu nem korábbi, hanem későbbi a négyzetes toronynál, akkor a toronynak azzal a járószintjével kell egykorúnak lennie, amely a belső küszöbszintjének magasságában került elő. Ez a szint a torony harmadik járószintje volt. A nagy torony eredeti járószintjét ugyanis később megemelték. Ez a második, habarcsos padlószint már fedi a torony belsejében talált két négyzetes pillér alapozását, amelyek így bizonyosan a négyzetes torony első építési korszakához tartoztak. E második szintbe 11. századi kerámiával datált cölöplyukakat ástak. Az ezekbe állított 18-20 cm átmérőjü, kövekkel kiékelt faoszlopokat szabályos $3 \times 3$ m-es raszterben rendezték el, és egy favázszerkezetes felépítményt hordozhattak. A faszerkezet egy oszlopsorának cölöplyukai a torony déli falán kívül is elökerültek. Itt a két keleti cölöplyuk dupla volt. Feltehetően a római torony romjai fölé a 11. században egy fatornyot emelhettek, ami dél felé túlnyúlott a római falakon. A délkeleti sarok mellett feltárt dupla cölöplyukak esetleg egy kapuszerkezetre utalhatnak. Ezt a fatornyot tủz pusztította el. A pusztulás során a faszerkezet tapasztásából kb. $20 \mathrm{~cm}$ vastag agyagos, paticsos réteg képződött a torony belsejében, amiből számos 11. századi kerámiatöredék került elő. E réteg felszínén, egy kormos foltban Szent László dénárját találták meg 1971-ben. A réteg lejárt felülete képezi azt a második középkori járószintet, amelyhez a kettős kapu belső küszöbszintje igazodik. A toronynak a Szent László pénzzel datált pusztulása utáni újjáépítés során épült fel a torony északkeleti sarka mellett egy árnyékszéktorony, a belső térben pedig egy középső kerek, valamint a falak mentén négy téglalap alakú kváderpillér, továbbá a torony új, lizénákkal és kettős kapunyílással tagolt keleti kváderfala. A déli toronyfal keleti része előtt Szőke Mátyás 1976-ban egy kövekkel alapozott habarcsos útfelületet tárt fel a torony harmadik járószintjének magasságában. Az út vonalában a déli toronyfal egy szakasza vízszintesen volt visszabontva a harmadik periódusú belső járószinthez igazodó szinten. Minden bizonnyal ez lehet a 11. század végi külső kapu újkorban kitermelt küszöbének és keretének helye. Feltehető, hogy már

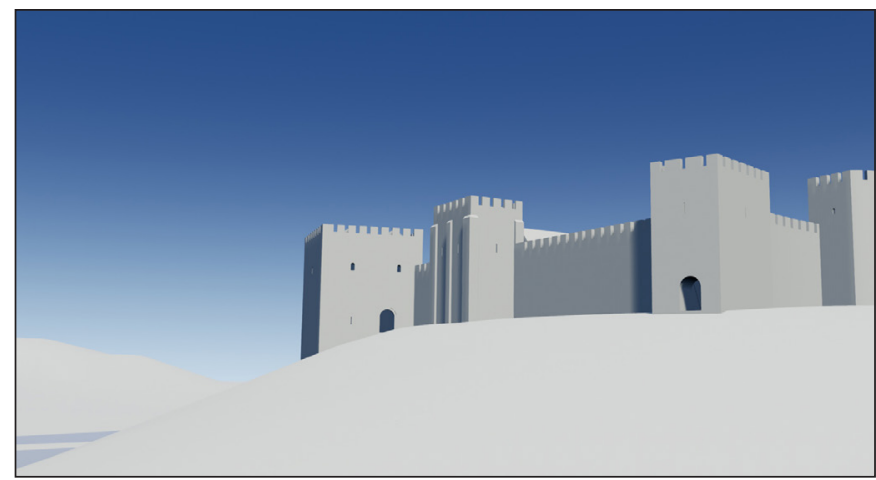

11. kép. A vár délnyugati tornyainak rekonstrukciós rajza kívülröl (rajz: Buzás Gergely)

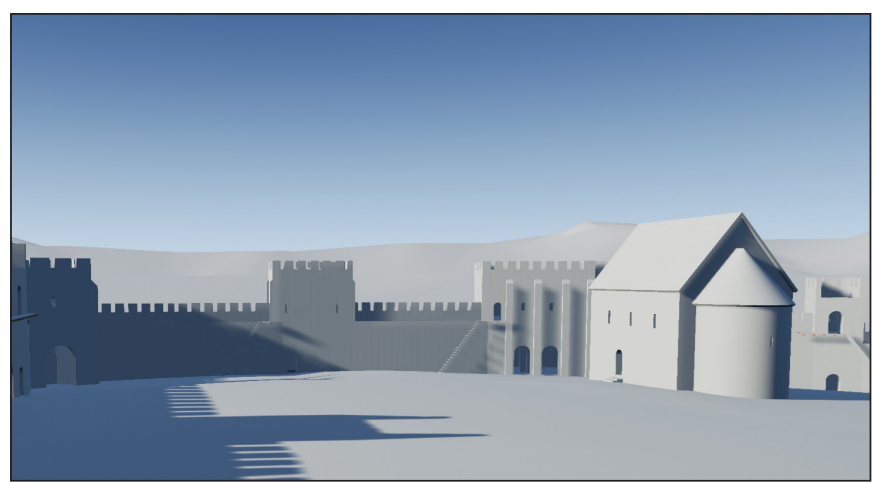

12. kép. A vár délnyugati tornyainak rekonstrukciós rajza belülröl (rajz: Buzás Gergely) 


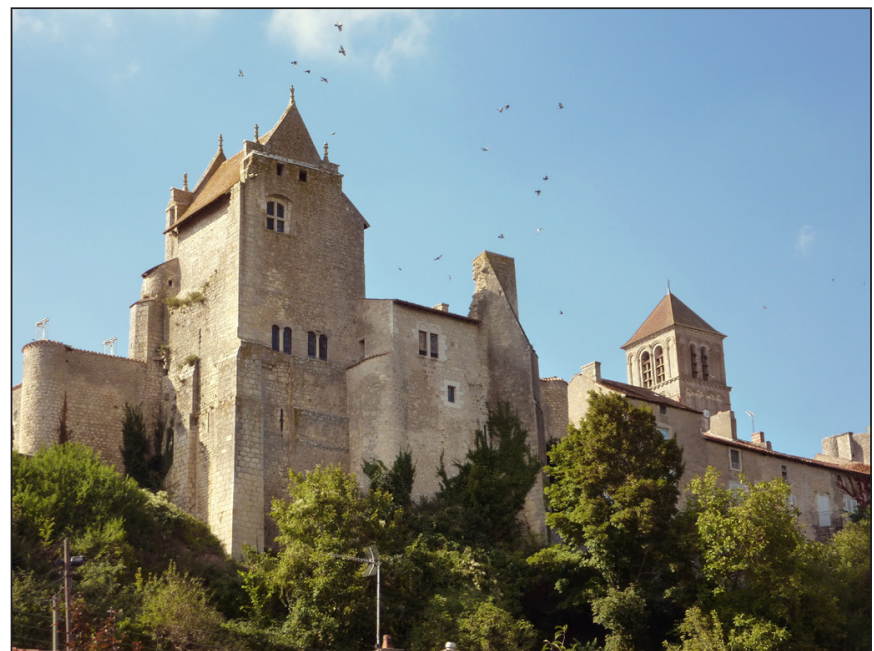

13. kép. Chauvigny, Château d'Harcourt

a korábbi, 11. századi periódusban is volt a fatorony külső kapuja, ugyanis az út alatt kerültek elő a fent említett dupla cölöplyukak.

A mindhárom feltárt torony középkori periódusára jellemző lizénás, kváderes falazásmód és fehér, kavics nélküli habarcs alapján ezeket az építkezéseket egykorúnak kell tartanunk (11-12. kép). Így a nagy torony utolsó periódusát megelőző égésrétegben talált Szent László dénár az egész építési periódust keltezi. A tornyok környezetében egy másik Szent László érme is előkerült 2021-ben: a délnyugati várfal mögött, egy középkori égett réteg fölé épített felmenő falu középkori faház padlójáról. Ezek a pénzek arra vallanak, hogy valamikor Szent László korában a vár, vagy annak legalább a délnyugati része leéghetett, és római eredetü tornyai romba dőltek. A három torony újjáépítésére ezt követően kerülhetett sor.

A három torony átépítésére jellemző kváderes falazásmód nem áll egyedül a visegrádi várban. Szőke Mátyás megfigyelése szerint, az általa 1974-ben, a vár délkeleti sarkában feltárt kétosztatú középkori palotaépület szintén ilyen falazattal épült. E palotaépület két római köépület és több 9-11. századi koraközépkori gödörház helyén emelték a 11. században (Soproni \& SzŐKE, 1976).

A visegrádihoz hasonló lizénás faltagolású, négyszögletes toronyforma a 10. század végén jelent meg Normandiában és Loire-vidéken, majd a 11. és 12. század folyamán széles körben elterjedt Franciaországban és Angliában. E tornyok egyik csoportjánál a lizénákat a sarkokon nem kereszt alakban rendezték el, hanem L alakban a sarkokat körülölelve. Ebbe a csoportba tartozik a visegrádi lizénás torony is. Ez utóbbi változat egyaránt ismert Normandiában (Mesqui, 1997, 152) és Angliában is (Godall, 2011, 77-144). Ám ezek az emlékek későbbiek a visegrádi tornyoknál. A visegrádi lizénás toronyhoz funkcióját, formáját és méretét tekintve is a legközelebb a poitoui Chauvigny keleti városfalához csatlakozó, később a Château d'Harcourt-ba beépült torony áll (13. kép). A városfal külső oldalához épült $9 \times 10 \mathrm{~m}$-es alapterületü, lizénás torony első periódusa a város legmagasabb pontján álló, Château de Gouzon 13. századi donjonjába beépített $12 \times 12$, m-es alapterületü 11. századi toronnyal azonos formát mutat (14. kép). Chauvigny a 11. század eleje óta a poitiersi püspökök városa volt. A város sarkába már a 11. században felépült a püspök első lakótornya. A városfalak és a tornyok építésének pontos kora nem ismert, de feltehetően a püspöki lakótoronnyal együtt, egységes koncepció szerint készültek el (SAILHAN, 1975), valószínüleg még a 11. század folyamán.

A Szent László-kori visegrádi építkezések másik sajátossága a kívül egy, belül kétnyílású, középpil-

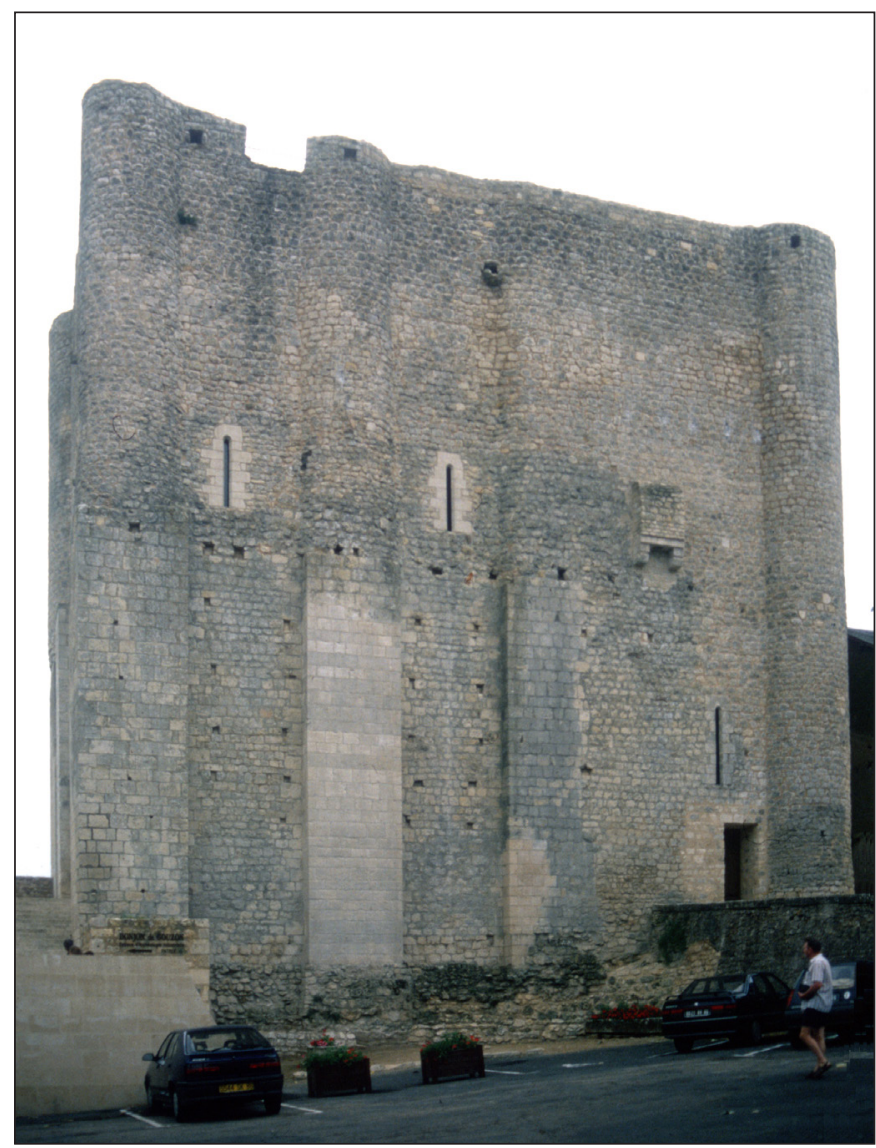

14. kép. Chauvigny, Château de Gouzon (fotó: Buzás Gergely) 
léres kapucsarnokkal ellátott kaputorony-forma. A visegrádi nagy kaputorony formailag legközelebbi párhuzama az 1158 után felépült gelnhauseni császári Pfalz kaputornya (BINDING, 1996, 262-292; 15. kép). Ez azonban évtizedekkel későbbi a visegrádinál, így legfeljebb egy mára elpusztult közös mintaképre gondolhatunk velük kapcsolatban.

\section{Történeti értelmezés}

Szent László korához kapcsolódik Visegrád egyetlen Árpád-kori említése a Képes Krónikában, miszerint: „László király pedig rajtakapta a gonoszságon Salamont, elfogta és Visegrádon börtönbe vetette." Ezen események előzményeként annyit közöl a krónika, hogy: László „, Országlásának negyedik esztendejében kibékült Salamonnal és elegendö költséget adott neki királyi szükségleteire. Az ország fóemberei azonban óvatosan elejét vették annak, hogy újra veszedelem és háborúság támadjon: nem

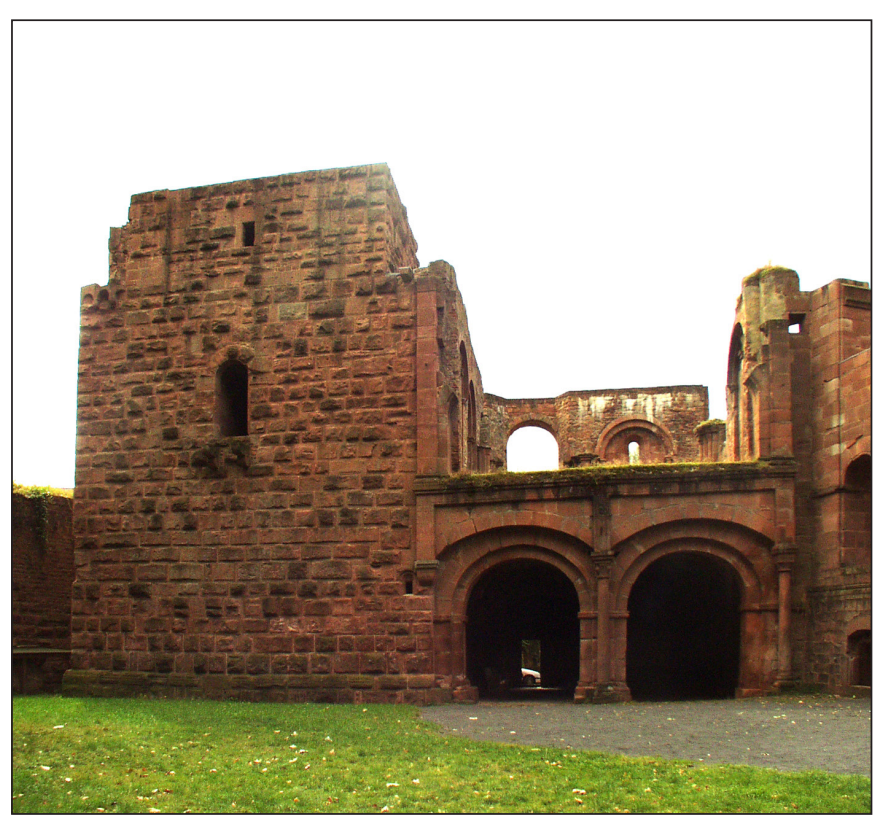

15. kép. Gelnhausen, a császári Pfalz kapuépítménye a várudvar felöl (fotó: Buzás Gergely) türték, hogy Salamonnal megosztozzon az országon...” (SRH I. 407; Geréb László fordítása). A László és Salamon közti 1080 körüli kiegyezés minden bizonnyal IV. Henrik 1079-es tavaszi, magyarországi hadjáratának következménye volt (PAULER, 1899, 145), amelyről a László-párti magyar krónika mélyen hallgat, valószínüleg nem ok nélkül. Amennyiben IV. Henrik ekkor is az 1074-es, Vácig hatoló nyári hadjáratának útvonalát követte, úgy ennek során ostromolhatták meg és gyújthatták fel a visegrádi várat is. Ennek az ostromnak lehetett a következménye a visegrádi ispánság utódaként értelmezhető esztergomi ispánság feltünése ugyanebben az évben (Zsoldos, 2001, 39). Az 1079-ben említett Gurcu, esztergomi ispán László embere volt, hiszen apja Péter, az 1074-es kemeji csatában, Géza mellett harcolva esett el (Zsoldos, 1995). Az ő Esztergomba költözésének oka alighanem az lehetett, hogy a visegrádi várat elveszítette. László mindenesetre rákényszerült, hogy Salamonnak királyhoz méltó udvartartást és jövedelmet biztosítson, bár az ország megosztására nem került sor. Valószínü, hogy Salamonnak - az általa már amúgy is elfoglalt - Visegrádot és vele együtt a hozzá tartozó pilisi erdőséget engedhette át, amint nem sokkal később Kálmán király Álmos herceget is így próbálta kárpótolni az őt megillető hercegség helyett. Ez lehetett az oka annak, hogy amikor később László megszegte az egyezséget és börtönbe vetette Salamont, arra éppen Visegrádon került sor. Még ezt megelözően állíthatta helyre Salamon király új székhelyeként az 1079ben megszerzett visegrádi várat. A császári támogatással hazatérő Salamon új rezidenciájának kiépítéséhez minden bizonnyal a császári udvarból hozhatott magával építőmestereket. Ott pedig könnyen szolgálatába fogadhatott egy olyan építészt is, aki az 1077 végén elhunyt francia származású anyacsászárné, Salamon anyósa, Poitoui Ágnes udvartartásból került oda, és járatos volt a korabeli Nyugat-Európa és Németország, de különösképpen Poitou grófság várépítészetének legkorszerübb formáiban.

\section{FeLHASZnÁLT IRODALOM}

Binding, Günter (1996). Deutsche Königspfalzen von Karl dem Großen bis Friedrich II (765-1240). Darmstadt: Wissenschaftliche Buchgesellschaft.

Boruzs, Katalin (2021). Adalékok a Sibrik-dombi erőd római kori történetéhez. In Buzás G. (szerk.), „,Visegrád, Visegrád! Hol hajdani fényed?” Tanulmányok Szőke Mátyás 80. születésnapjára (pp. 9-24). Visegrád: Magyar Nemzeti Múzeum Mátyás Király Múzeuma. 
Boruzs Katalin - Buzás Gergely• Salamon király tornyai

Buzás, Gergely, Boruzs, Katalin, Merva, Szabina \& Tolnai, Katalin (2014). A kora középkori kontinuitás kérdése a visegrádi későcsászárkori erődben a legújabb régészeti kutatások tükrében. Magyar Régészet 3 (1) [2014 tavasz], 1-8.

Buzás, Gergely, Boruzs, Katalin, Merva, Szabina \&Tolnai, Katalin (2017). Régészeti kutatások a visegrádi Sibrik-dombon. Archaeological Investigations on Sibrik Hill at Visegrád. Communicationes Archaeologicae Hungaricae 2017, 193-234.

Godall, John (2011). The English Castle. 1066-1650. New Haven - London: Yale University Press.

Mesqui, Jean (1997). Châteaux forts et fortifications en France. Paris: Flammarion.

Pauler, Gyula (1899). A magyar nemzet története az Árpádházi királyok alatt. Budapest.

Sailhan, Pierre (1975). La ville forte de Chauvigny. Le Pays Chauvinois 14 (1975), 2-21.

Soproni, Sándor \& Szőke, Mátyás (1972). Visegrád-Várkert. Régészeti Füzetek I/25 (1972), 43-44.

Soproni, Sándor \& Szőke, Mátyás (1975). Visegrád-Várkert. Régészeti Füzetek I/28 (1975), 69-70.

Soproni, Sándor \& Szőke, Mátyás (1976). Visegrád-Várkert. Régészeti Füzetek I/29 (1976), 49.

Soproni, Sándor \& Szőke, Mátyás (1977). Visegrád-Sibrik domb. Régészeti Füzetek I/30 (1977), 28.

Soproni, Sándor (1954). A visegrádi római tábor és középkori vár. - A Roman Camp and Medieval Castle in Visegrád. Archaeologiai Értesítö 81 (1954), 49-53.

SRH = Scriptores Rerum Hungaricarum. I-II. Ed. Emericus Szentpétery. Budapest, 1937-1938. Reprint: Budapest, 1999.

Zsoldos, Attila (1995). Péter és Gurka (Gurcu) ispán nemzetsége. Történelmi Szemle 37/3 (1995), 345-351.

Zsoldos, Attila (2001). Pest megye az Árpád-korban. In Torma I. \& Zsoldos A. (eds), Pestmegye monográfiája I/2. A honfoglalástól 1686-ig (pp. 31-73). Budapest: Pest Megye Monográfia Közalapítvány. 